\title{
Working Time and the Controller
}

\author{
By Zoltán Musinszki ${ }^{1, *}$, Gábor Mélypataki ${ }^{2}$, and Noémi Hajdú ${ }^{3}$ \\ ${ }^{1}$ Associate Professor, University of Miskolc, Hungary, stmusiz@uni-miskolc.hu \\ ${ }^{2}$ Assistant Professor, University of Miskolc, Hungary, jogmega@uni-miskolc.hu \\ ${ }^{3}$ Associate Professor, University of Miskolc, Hungary, margn@uni-miskolc.hu
}

\begin{abstract}
This article seeks to reveal whether the labour regulations of a given Member State are applicable to a specific group of employees working as controllers and whether the working time regulations, which have been part of international law since the early 20th century, can still be respected.

A cross-sectional study of employers' expectations of controllers was carried out based on three data collections, which took place in January 2019, January 2020 and May 2020. The structure of the job advertisements was used as a basis for defining the criteria to be examined, and the tasks, expectations and requirements were analysed. In the case of controllers, flexibility and co-operation are among the most important competences to be expected, in addition to the required precision.

It follows from the above that working time rules show a high correlation with competencies. This is particularly true in the context of the fact that the most important job duties required by employers are always linked to time periods. These tasks require more skill, attention and time from the controller at a given moment in time than general work. As the job of a controller falls somewhere between the typical and atypical forms of work in terms of working time use, semiflexible working hours might be a solution. We believe that the lessons of our study may also be applied to other jobs. The special work schedules and working time rules that have become common during the Coronavirus pandemic further increase the topicality of this matter.
\end{abstract}

Keywords: controller, decision support, COVID-19, working time, atypical work

\section{Introduction}

One of the most important developments in labour law over the last one hundred years has been the evolution of working time and working conditions, driven primarily by the international jurisprudence developed by ILO, which has had a significant impact on national rules.

Changes in working time fundamentally determine the actual content, frequently the quality of work, and the possibility of applying additional labour law guarantees. With decrease in working hours, actual work activity has also decreased, although not linearly. This is because technological progress can also improve the efficiency of work. The past one hundred years, 
which may be considered as the century of changing working hours, have seen a complete transformation in the range of skills required for work under the conditions of today's world. The basis for this set of skills is, on the one hand, labour law regulations. On the other hand, the other basis for the development of competences for work is that labour law guarantees have also gone their own way and create the possibility for the individual to develop. The development of labour law guarantees in Hungarian law has followed the international trend with a slight delay. Social, economic and cultural rights were included already in the state socialist model, as opposed to the guarantee of political and civil rights. The establishment of labour inspectorates and restrictions on the termination of employment were important steps in this process. These are important elements in employment relationships and in the systems of relations between the parties.

With regard to the necessary competences, this study focuses on the most relevant ones from a labour law perspective, in the context of working time.

\section{ILO Convention No 1 (ILO 1) - Hours of Work (Industry) Convention}

The first convention is the 1919 convention limiting the working time of industrial companies to eight hours a day or 48 hours a week. One of the most important parts is the establishment of the principle of working 8 hours a day or 48 hours a week as a basic principle (Kiss, 2001).

The second one clarifies what basically counts as an industrial undertaking. The convention considers as industrial undertakings mines, plants in which articles are manufactured, altered, cleaned, repaired, or ornamented, including shipbuilding and the generation, transformation, and transmission of electricity or motive power of any kind. Basically, all construction-related enterprises, including railways, harbours, docks, canals, roads, telegraphs, telecommunication equipment, gas and water utilities, and companies in the transport sector, whether transport is performed by road, rail or sea. (ILO 1 Articles 3-4)

Basically, working 48 hours a week or 8 hours a day applies to everyone (Lee et al., 2007). The convention provides three exceptions to this.

One is plants run by family labour, which has been present in labour law up to date. In accordance with Article 92 (2) of the Labour Code, if the employer or the owner of the employer is a relative of the employee, the working day may be up to 12 hours (ILO1 Articles 6-8).

An exception for persons holding a leading position in a supervisory body in the management of a company, coupled with the possibility to work informal hours. This is of particular importance for controllers (ILO1 Article 9).

This includes companies with no employee representation, where the company deviates from a minimum of eight hours a day on some days and therefore works more than eight hours on all other days, and other trades where the employees' schedules may cover several periods in a day. However, the employee's weekly working time may not exceed 48 hours even in this case. The very promulgation of this rule was a major progress. Out of these 48 hours, international 
and national rules have cut another 8 hours. The average working week in Hungarian law is also 40 hours, but in no case may it exceed 48 hours a week, including overtime. This will be nuanced by the reference timeframe to be discussed below, when one can effectively work more than 48 hours, but when averaged back over the working timeframe, the time will still not be more.

Exceptions to this include accidents, interventions of a "force majeure" nature in the case of plants in danger of accidents, or any intervention necessary to avoid serious disruption to the regular operation of the company. In the case of such interventions, the average weekly working time should not exceed 56 hours and should not affect the rest days provided for by national law for employees to receive the weekly rest day compensation to which employees are entitled. For industrial undertakings, public authorities can define the tasks to be performed outside working time limits in the case of preparatory or additional work, and the category of employees employed for intermittent work, with periodic exceptions to allow companies to appropriately tackle the greater workload they are required to undertake. (ILO1 Articles 1115). In such a case, the Member State may, after consulting the employees and workers' organisations concerned, increase the working time.

These processes and matters relating to the validity of agreements must also be communicated to the International Labour Office by the state that is a party to the Convention. The International Labour Office publishes an annual report on these disclosed data to the International Labour Organisation Conference. In order to ensure that working hours are observed, the start and end times of shifts for multi-shift work, subject to mandatory scheduling, must be posted in a conspicuous place within the establishment, and the times so posted may be changed by a notice and in a manner approved by the government. Similarly, the rest periods that fall during working time and are not part of working time should be communicated. It is an infringement of the law if any person is employed outside working hours during a rest period.

A specific feature of the ILO conventions is that they provide an opportunity for relaxed application. This is mainly granted for countries with weaker economic potential. These were expressed in the form of reservations, and in addition, the states were required to constantly justify any referenced difficult economic situation. These conventions have been concluded for Japan, India, China, Persia, Siam and Greece, which are allowed to postpone the introduction of working hours in some industrial plants specific to the given country, and Romania, which was only obliged to apply them from 1924. Only a ratified Member State has the right to denounce the Convention after ten years from the date of ratification. Such a denunciation enters into force after one year, so as to know exactly which states are parties. The Governing Body of the International Labour Office reports once every 10 years on which Member States have been covered by this Convention (ILO 1 Closing provisions).

It is an interesting fact that Hungary is still not a party to this 1919 convention on working time. Hungarian law exceeds the level of protection ensured by the Convention and it is unlikely that Hungary will consider ratifying the Convention in the near future. This case is similar to the story of Convention 102 on the minimum standards of social security. The 
Hungarian Government conducted a study on this subject, but in the final study the experts concluded that it would not add anything to the national regulation. Unfortunately, the legislator did not feel the symbolic significance of its transposition and probably not of the ratification of Convention 1 either.

\section{Research methodology}

The logical framework of our research was described by G. Fekete et al. (2011), G. Fekete - Lipták (2011), Szucsne Markovics (2015, 2019). In methodological issues, we also used Hajdú et al. (2019), Lipták (2013), Polonkai \& Szucsne Markovics (2018), Veresné Somosi \& Balaton (2020), and Veresné Somosi \& Varga (2021).

A cross-sectional study of employers' expectations of controllers was performed on the basis of three data collections, which took place in January 2019 (Gyenge, 2019), January 2020 (Doszpoly, 2020) and May 2020 (Nácsa, 2020). The source of the data was the controller job advertisements available on profession.hu. One hundred of the available job vacancies were randomly selected in 2019, 103 in January 2020 and 112 in May 2020. However, since the number of the population is unknown, from the three samples no conclusions can be drawn for the entire population, and so this study serves to identify trends.

The classification of companies as advertisers by size was based on the headcount of their employees, sales revenue and the balance-sheet total. For this purpose, the companies' electronically published reports were used (https://ebeszamolo.im.gov.hu/oldal/beszamolo_kereses). For companies that do not keep their books in HUF, the MNB exchange rate quoted at the end of the financial year was used for the conversion (https://www.mnb.hu/arfolyam-lekerdezes). Thus, 53 large, 23 medium-sized and 24 small enterprises were included in the sample in 2019; 54 large, 9 medium-sized and 10 small enterprises in January 2020; and 46 large, 30 medium-sized and 17 micro- and small enterprises in May 2020. As of January 30 May 2020, 19 advertisers could not be identified.

The structure of the job advertisements was used to define the set of criteria to be analysed, where (1) tasks, (2) expectations and requirements, and - irrelevant for our topic - (3) the supply side were analysed.

In order to maintain manageability, we had to standardise our raw database, as each job advertisement contained a new task or a new expectation compared to the previous ones, or simply two tasks with the same meaning were worded differently. In order to achieve the results standardised categories were set up. The merging of tasks and requirements was partly made subjectively. Variables with similar meanings and variables with low frequencies that belong to the same group were included in the same group. After data compression and organisation, qualitative methods were used, including text analysis and content analysis. 


\section{Controller personality traits and competencies based on job advertisements}

The competences required by the employers to fill the jobs were assessed in five groups: personality traits, professional competencies and knowledge, education, professional experience and language skills.

At the beginning of this millennium, in the Hungarian controlling literature (Körmendi \& Tóth, 2002, Maczó et al., 2001) the expectations vis-a-vis the controller were divided into two main groups: professional expectations and personality traits. The personality traits often mentioned in their tests include, for example: logical thinking, analytical and synthesising skills, creativity, interest in new information, propensity to work in teams, ability to lead teamwork, persuasiveness, good communication skills, good written and oral expression, co-ordination, motivation, and diplomacy.

In a book published in 2006, Körmendi and Tóth identified the following as the most important personality traits of a controller: creativity, conflict management, precision, openness (the controller is the person most informed about genuine economic processes, and therefore the first to recognise the need for change), clarity of vision and expression, sense of responsibility, objectivity and reliability.

In 2013, IFUA Horváth \& Partners conducted the first Hungarian controlling competence survey with the participation of nearly 300 professionals with many years of experience and higher education in economics. The aim of the survey was to identify the competency traits that a controlling professional should necessarily possess in the current economic environment. The personality traits reflected in the research are fully reflected in the advertisements. The survey was based on a competency model consisting of 16 elements, which may be grouped into four main categories: (1) professional; (2) methodological; (3) social; (4) personal relations. IFUA Horváth \& Partners also conducted a survey in Germany, with findings shown in Table 1. 
Table 1: Findings of German and Hungarian competency surveys

\begin{tabular}{|l|l|l|l|}
\hline \multicolumn{2}{|c|}{ Hungarian competence ranking } & \multicolumn{2}{c|}{ German competence ranking } \\
\hline 1.Analytical thinking & 4,1 & 1.Analytical thinking & 4,0 \\
\hline 2.Load capacity & 4,1 & 2.Load capacity & 3,9 \\
\hline $\begin{array}{l}\text { 3.Customer orientation / } \\
\text { consulting competence }\end{array}$ & 4,0 & 3.Team orientation / cooperation & 3,9 \\
\hline 4.Team orientation / cooperation & 3,9 & 4.Assuming conflicts & 3,8 \\
\hline 5.Implementation capability & 3,9 & $\begin{array}{l}\text { 5.Business understanding, } \\
\text { business knowledge }\end{array}$ & 3,8 \\
\hline 6.Conscience, neutrality & 3,9 & 6.Conscience, neutrality & 3,7 \\
\hline 7.Assuming conflicts & 3,9 & 7.Communication skills & 3,7 \\
\hline 8.IT competence* & 3,8 & 8.Controlling expertise & 3,7 \\
\hline 9.Performance orientation & 3,8 & 9.Implementation capability & 3,7 \\
\hline 10.Leadership competence & 3,8 & $\begin{array}{l}\text { 10.Customer orientation / } \\
\text { consulting competence }\end{array}$ & 3,7 \\
\hline 11.Solution orientation & 3,8 & 11.Empathy / sensitivity & 3,6 \\
\hline $\begin{array}{l}\text { 12.Business understanding, } \\
\text { business knowledge }\end{array}$ & 3,7 & 12.Performance orientation & 3,6 \\
\hline 13.Communication skills & 3,7 & 13.Solution orientation & 3,5 \\
\hline 14.Proactivity & 3,7 & 14.Leadership competence & 3,5 \\
\hline 15.Controlling expertise & 3,7 & 15.Proactivity & 3,5 \\
\hline 16.Empathy / sensitivity & 3,5 & & \\
\hline
\end{tabular}

1. not important, 2. less important, 3. important, 4. very important, 5. essential

* Only included in the Hungarian survey separately

Source: Solti, 2013

An analysis of the frequency of the key personality traits identified in the job advertisements shows that an analytical approach, thorough and demanding work and a system approach play a key role. Proactivity, communication skills, the ability to work independently and problemsolving skills are also frequently mentioned.

The surveys concluded that analytical thinking is becoming increasingly valued. In addition to the mechanical compilation of reports, the role of the controller as an analyst and advisor has increased. In addition to classic controlling tasks (planning, variance analysis), customer orientation and advisory skills are now also required, and in addition to the technical production 
of reports, support to decision-makers in their interpretation is also required. At the same time, the increasing and continuous demand for information means that workload and work capacity are becoming increasingly important in daily work (Solti, 2013).

The non-professional expectations set out in the advertisements are considerably more varied than the expected tasks. While they were processed and organised, the findings of the national and international research presented here were considered guiding.

Looking at personal competencies in 2019, it can be concluded that, in line with the theoretical background of the topic (Tóth \& Zéman, 2017, Horváth et al., 2015, Fenyves et al., 2016, and Gleich et al., 2016), firms have a high demand for an analytical approach and precision.

Good communication skills, the ability to work independently and problem-solving skills were significant in both years.

Table 2. clearly shows that an analytical approach is a competency often expected regardless of the size of the company. Thorough and demanding work is expected in particular by SMEs. A systems approach is one of the personality traits most often required in medium-sized and large companies. Overall, the requirement of good communication skills is relatively more common in the case of small businesses compared to other sizes. For medium-sized enterprises, this role is assigned to autonomy and a systems approach.

Table 2: Personal competencies by company size in January 2019, January 2020 and May 2020

\begin{tabular}{|c|c|c|c|c|c|c|c|c|c|}
\hline & $\begin{array}{l}\text { Professional competence / } \\
\text { Company size }\end{array}$ & $\begin{array}{l}\text { Analyst } \\
\text { approach }\end{array}$ & Precision & $\begin{array}{c}\text { Communication } \\
\text { skills }\end{array}$ & $\begin{array}{l}\text { Independent } \\
\text { work }\end{array}$ & $\begin{array}{c}\text { Problem- } \\
\text { solving } \\
\text { skills }\end{array}$ & Flexibility & $\begin{array}{c}\text { High load } \\
\text { capacity }\end{array}$ & \begin{tabular}{|} 
System \\
approach
\end{tabular} \\
\hline \multirow{6}{*}{ January 2019} & Small business & $45,83 \%$ & $58,33 \%$ & $54,17 \%$ & $50,00 \%$ & $29,17 \%$ & $50,00 \%$ & $33,33 \%$ & $16,67 \%$ \\
\hline & Medium enterprise & $60,87 \%$ & $52,17 \%$ & $39,13 \%$ & $34,78 \%$ & $39,13 \%$ & $56,52 \%$ & $26,09 \%$ & $21,74 \%$ \\
\hline & \begin{tabular}{|l|} 
Large enterprise \\
\end{tabular} & $54,72 \%$ & $50,94 \%$ & $41,51 \%$ & $33,96 \%$ & $32,08 \%$ & $37,74 \%$ & $22,64 \%$ & $24,53 \%$ \\
\hline & \begin{tabular}{|l|} 
Average \\
\end{tabular} & $54,00 \%$ & $53,00 \%$ & $44,00 \%$ & $38,00 \%$ & $33,00 \%$ & $45,00 \%$ & $26,00 \%$ & $22,00 \%$ \\
\hline & Frequency maximum & $60,87 \%$ & $58,33 \%$ & $54,17 \%$ & $50,00 \%$ & $39,13 \%$ & $56,52 \%$ & $33,33 \%$ & $24,53 \%$ \\
\hline & Deviation from average & $6,87 \%$ & $5,33 \%$ & $10,17 \%$ & $12,00 \%$ & $6,13 \%$ & $11,52 \%$ & $7,33 \%$ & $2,53 \%$ \\
\hline \multirow{6}{*}{ January 2020} & Small business & $30,00 \%$ & $80,00 \%$ & $10,00 \%$ & $50,00 \%$ & $30,00 \%$ & $20,00 \%$ & $40,00 \%$ & $10,00 \%$ \\
\hline & Medium enterprise & $22,20 \%$ & $88,90 \%$ & $22,20 \%$ & $44,40 \%$ & $33,30 \%$ & $22,20 \%$ & $11,10 \%$ & $0,00 \%$ \\
\hline & Large enterprise & $70,40 \%$ & $57,40 \%$ & $37,00 \%$ & $33,30 \%$ & $16,70 \%$ & $5,60 \%$ & $13,00 \%$ & $20,40 \%$ \\
\hline & Average & $48,54 \%$ & $50,49 \%$ & $33,01 \%$ & $29,13 \%$ & $22,33 \%$ & $10,68 \%$ & $13,59 \%$ & $11,65 \%$ \\
\hline & Frequency maximum & $70,40 \%$ & $88,90 \%$ & $37,00 \%$ & $50,00 \%$ & $33,30 \%$ & $22,20 \%$ & $40,00 \%$ & $20,40 \%$ \\
\hline & Deviation from average & $21,86 \%$ & $38,41 \%$ & $3,99 \%$ & $20,87 \%$ & $10,97 \%$ & $11,52 \%$ & $26,41 \%$ & $8,75 \%$ \\
\hline \multirow{6}{*}{ May 2020} & Small business & $52,94 \%$ & $35,29 \%$ & $52,94 \%$ & $17,65 \%$ & $29,41 \%$ & $0,00 \%$ & $17,65 \%$ & $17,65 \%$ \\
\hline & Medium enterprise & $66,67 \%$ & $73,33 \%$ & $33,33 \%$ & $46,67 \%$ & $20,00 \%$ & $10,00 \%$ & $20,00 \%$ & $50,00 \%$ \\
\hline & \begin{tabular}{|l|} 
Large enterprise \\
\end{tabular} & $56,52 \%$ & $32,61 \%$ & $21,74 \%$ & $32,61 \%$ & $17,39 \%$ & $15,22 \%$ & $8,70 \%$ & $36,96 \%$ \\
\hline & Average & $59,14 \%$ & $46,24 \%$ & $31,18 \%$ & $34,41 \%$ & $20,43 \%$ & $10,75 \%$ & $13,98 \%$ & $37,63 \%$ \\
\hline & Frequency maximum & $66,67 \%$ & $73,33 \%$ & $52,94 \%$ & $46,67 \%$ & $29,41 \%$ & $15,22 \%$ & $20,00 \%$ & $50,00 \%$ \\
\hline & Deviation from average & $7,53 \%$ & $27,09 \%$ & $21,76 \%$ & $12,26 \%$ & $8,98 \%$ & $4,47 \%$ & $6,02 \%$ & $12,37 \%$ \\
\hline
\end{tabular}

Source: based on Gyenge, 2019, Doszpoly, 2020 and Nácsa, 2020

During the third survey, in May 2020, professional competencies were also tested. In terms of the frequency of professional competences, see Table 3, familiarity with MS Office is the clear leader. SAP is also relatively frequently required compared to the other competencies. The 
knowledge of BI systems and SQL only appeared in 6 and 4 job advertisements respectively, i.e. the labour market has not yet followed the shift towards BI culture as it appears in the literature. The analysis of the expectations regarding professional competences by company size has led to the striking conclusion that only MS Office skills show a high prevalence for all three company sizes. SAP knowledge is becoming increasingly important as companies grow in size. A similar phenomenon can be observed for familiarity with SQL. Apart from the MS Office expectations, small businesses did not formulate any other substantive expectations. In addition to MS Office, medium-sized businesses often require accounting skills, while the large corporate sector requires SAP skills.

\begin{tabular}{|c|c|c|c|c|c|c|c|c|c|c|c|c|c|}
\hline $\begin{array}{l}\text { Professional competence } \\
\text { / Company size }\end{array}$ & $\begin{array}{l}\text { Knowledge } \\
\text { of Bl system }\end{array}$ & IFRS & $\begin{array}{c}\text { Good } \\
\text { presentation } \\
\text { skills }\end{array}$ & $\begin{array}{c}\text { Advanced IT } \\
\text { skills }\end{array}$ & $\begin{array}{c}\text { MS Office } \\
\text { skills }\end{array}$ & $\begin{array}{c}\text { Up-to-date } \\
\text { accounting } \\
\text { and } \\
\text { taxation } \\
\text { knowledge } \\
\end{array}$ & $\begin{array}{l}\text { Programming } \\
\text { skills }\end{array}$ & \begin{tabular}{c|} 
SAP \\
knowledge
\end{tabular} & \begin{tabular}{c|} 
SQL \\
knowledge
\end{tabular} & $\begin{array}{c}\text { Accounting } \\
\text { skills }\end{array}$ & $\begin{array}{c}\text { GDPR } \\
\text { knowledge }\end{array}$ & Accountant & \begin{tabular}{c|} 
VBA \\
knowledge
\end{tabular} \\
\hline Small business & $0,00 \%$ & $5,88 \%$ & $0,00 \%$ & $0,00 \%$ & $64,71 \%$ & $0,00 \%$ & $0,00 \%$ & $0,00 \%$ & $0,00 \%$ & $0,00 \%$ & $5,88 \%$ & $0,00 \%$ & $0,00 \%$ \\
\hline Medium enterprise & $6,67 \%$ & $0,00 \%$ & $0,00 \%$ & $0,00 \%$ & $90,00 \%$ & $3,33 \%$ & $6,67 \%$ & $10,00 \%$ & $6,67 \%$ & $23,33 \%$ & $0,00 \%$ & $0,00 \%$ & $0,00 \%$ \\
\hline Large enterprise & $4,35 \%$ [ & $0,00 \%$ & $0,00 \%$ & $2,17 \%$ & $76,09 \%$ & $0,00 \%$ & $2,17 \%$ & $19,57 \%$ & $8,70 \%$ & $2,17 \%$ & $0,00 \%$ & $2,17 \%$ & $2,17 \%$ \\
\hline Average & $4,30 \%$ & $1,08 \%$ & $0,00 \%$ & $1,08 \%$ & $78,49 \%$ & $1,08 \%$ & $3,23 \%$ & $12,90 \%$ & $6,45 \%$ & $8,60 \%$ & $1,08 \%$ & $1,08 \%$ & $1,08 \%$ \\
\hline Frequency maximum & 6,67\% & $5,88 \%$ & $0,00 \%$ & $2,17 \%$ & $90,00 \%$ & $3,33 \%$ & $6,67 \%$ & $19,57 \%$ & $8,70 \%$ & $23,33 \%$ & $5,88 \%$ & $2,17 \%$ & $2,17 \%$ \\
\hline Deviation from average & $2,37 \%$ [ & $4,81 \%$ & $0,00 \%$ & $1,10 \%$ & $11,51 \%$ & $2,26 \%$ & $3,44 \%$ & $6,66 \%$ & $2,24 \%$ & $14,73 \%$ & $4,81 \%$ & $1,10 \%$ & $1,10 \%$ \\
\hline
\end{tabular}

Source: Nácsa, 2020 p. 42.

Higher education was required in nearly 90 per cent of the job advertisements surveyed. (In two cases the advertisement included a secondary level of education, while in the other cases the advertisements did not contain any requirements regarding education.) All the small businesses included in the sample required relevant tertiary qualifications. In the case of medium-sized and larger enterprises, it is also often the case that only tertiary education is expected, regardless of the field of training.

Employers set language requirements in 70.54 per cent of job advertisements. Most often - for more than 90 per cent of the organisations that have language requirements - the need is for intermediate or advanced English language skills. The correlation between company size and language skills gives an interesting picture. Small businesses most often expect employees to have a high level of English. Medium-sized companies most often do not ask for language skills. Large companies most often expect a controller to have an intermediate level of English, followed by a higher level of English.

\section{Conclusions}

The research revealed that all three business sectors consider precision to be important. Hungarian labour law and labour market rules do not directly regulate SMEs. However, this does not mean that there are no specific labour market instruments to promote employment. When we translate the term "precision" into the language of labour law, a complex category emerges. One of the elements of this complex category is set out in Article 52 (1) (a) of the Labour Code, which obliges the employee to appear at the time and place specified by the 
employer in a condition fit for work. This is strongly linked to the start of working hours. Simultaneously, the employee must start work and perform the preparatory tasks included in his or her working hours. At the end of the working day, he or she must perform the same finishing activities. The employee must maintain his or her fitness for work until the end of the working day. Full compliance with the obligations set out in Article 52 of the Labour Code may be understood as an expression of "precision" in labour law terms. An example includes but is not limited to Article 52 (1) c. According to the above-quoted section, the employee is required to perform his or her work personally, with the competency and care reasonably expected of him/her in general, and in accordance with the rules, regulations, instructions and customs applicable to his or her work. Naturally, all of these statutory provisions require that precise work is carried out within the working hours set by the employer (Bankó et al., 2017, Jakab \& Tóth, 2018). The Labour Code is unable to specifically define the concept of precision, as it is a non-legal concept, but we can describe it in terms of a set of rights and obligations. The concept of precision, if we look at it in terms of working time, is seen in terms of work done on time and in the working hours invested in an appropriate extent. The question is, however, to what extent the precision work that is defined in the controller job in question can be fitted into the traditional working time framework. This issue is also central because the controller is not generally subject to specific labour law rules. The controller is not a managerial employee in the majority of cases, but a subordinate employee involved in decisions supporting the management (Musinszki et al., 2019). For this reason, in most cases, the application of more flexible labour law rules, such as informal working hours, applicable to managers, is not an option. In the case of controllers, flexibility and co-operation are among the most important competences to be expected, in addition to the required precision.

As the controller's job is related to the management of the company, it is likely that working 40 or 48 hours a week and overtime is not always enough to get the job done. In such a case, one of the atypical working arrangements could be the solution, or the application of a settlement period, which is essentially a working time framework without a working time frame. In accordance with Article 98 (1) of the Labour Code, in the absence of a working time frame, working time may also be allocated in such a way that the employee completes the weekly working time determined on the basis of the daily working time and the general work schedule during a longer period (accounting period) determined by the employer, starting in the relevant week. This is a legal provision to allow the employee to be credited for any overtime worked within a given period, or for less than full-time work (Kiss, 2020). Its use is primarily related to the performance of project tasks, but its application is highly controversial, not only at the national but also at the international level (Fodor, 2016). Atypical forms of work, including flexible work, might also come into play. This would typically include the legal institution of teleworking and the legal status of a managerial employee.

Properly defined working hours also have a significant impact on employee morale and satisfaction (Máté, 2018). In the context of highlighting and defining competences, it is also important to address issues not surveyed in this study, such as whether the understanding of flexibility by employees and employers coincides. Such an analysis could lead to the emergence of a definition for problematic concepts, like for example work-life balance. (Sipka 
\& Zaccaria, 2020). The duty to inform also plays an important role in overcoming problems in interpretation (Tóth \& Pruberger, 2020).

Kun (2019), referring to the idea of György Lörincz, points out that the introduction of the legal concept of "semi-occasional work" into labour law might be justified. Partially flexible work would leave some room for the employee's decision-making competence as regards the workplace and/or working hours. In the controller's and similar decision support jobs, this might be a solution that serves to meet the requirements of both flexibility and security. This can be said in light of the fact that the requirement to work independently scores high in all sectors, and is even included among the top three competences in the small business sector.

It follows from the above that working time rules show a high correlation with competencies. This is particularly true in the context of the fact that the most important job duties required by employers are always linked to time periods. They usually do not include all year-round tasks, rather certain tasks linked to specific periods are highlighted. These tasks require more skill, attention and time from the controller at a given moment in time than general work. As the job of a controller falls somewhere between the typical and atypical forms of work in terms of working time use, the above-mentioned semi-flexible working hours might be a solution.

\section{Acknowledgement}

This research was supported by the EFOP-3.6.2-16-2017-00007 project entitled Aspects of the Development of a Smart, Sustainable and Inclusive Society: Social, Technological and Innovative Networks in Employment and in Digital Economy. The project has been supported by the European Union, and co-financed by the European Social Fund and the Government of Hungary.

\section{References}

Bankó, Z., Berke, Gy. and Kiss, Gy. (2017). Kommentár a munka törvénykönyvéhez, Wolter Kluwer, Budapest,

Doszpoly, P. (2020): A digitális átalakulás hatása a kontrollerekkel szemben támasztott kompetenciaelvárások alakulására. University of Miskolc, Diploma Thesis

Fenyves, V., Kondorosi, F., Kerezsi, D., Dajnoki, K. 2016): Vezetői döntést segítő információk a munkaerővándorlás sajátosságai alapján, Controller Info, 4 (3), pp. 42-51.

Fodor T. G. (2016): A Munka Törvénykönyve munka- és pihenőidő szabályozásának uniós jogi megfelelőségéről, Magyar Munkajog, 2016/2, pp. 21-36.

Gleich, R., Losbichlerv, H., Rainer, M., Zierhofer, R. M. (2016): Unternehmenssteuerung im Zeitalter von Industrie 4.0: Wie Controller die digitale Transformation erfolgreich steuern, München, Haufe,

G. Fekete, É.; Dabasi-Halász, Zs.; Szép, T.; Lipták, K.; Osgyáni, G.; Baksa, S.; Kispataki, Cs. (2011): Önkormányzatok és civil szervezetek helyi foglalkoztatási kapacitásainak növelési lehetőségei, kutatási jelentés, Miskolc, 81 p. 
G. Fekete É., Lipták, K. (2011): Postmodern values in rural peripheries. Journal of Settlements and Spatial Planning 2:1. pp. 1-7.

Gyenge, N. (2019): A kontroller álláshirdetések mögöttes tartalma. University of Miskolc, Diploma Thesis

Hajdú, N., Lipták, K., Musinszki, Z. (2019): Probléma alapú tanulás a közgazdász képzésen In: Tóth, P., Horváth, K., Maior, E., Bartal, M., Duchon, J (Ed.) Neveléstudományi kutatások a Kárpát-medencei oktatási térben: Pedagogical Research in the Carpathian Basin Educational Space Komárno, Slovakia: Selye János Egyetem Tanárképző Kar (2019) pp. 352-361.

Horváth \& Partner (2015): Controlling, Út egy hatékony controllingrendszerhez. Saldo Kiadó, Budapest,

International Labour Organization (ILO) Convention. C001 - Hours of Work (Industry) Convention, 1919 (No. 1).

Jakab, N., Tóth, H. (2018): Flexicurity in Hungary from the more Vulnerabe Party's Point of View In: 5th International Multidisciplinary Scientific Conference on Social Sciences and Arts SGEM 2018 Sofia, STEF92 Technology Ltd., pp.153-160.

Kiss, Gy. (2001): A munkaidő megszervezésének egyes kérdései, in Kiss, Gy. (ed.): Az Európai Unió munkajoga, Budapest, Osiris, pp. 351-352.

Kiss, Gy. (2020): Munkaidő, in Kiss, Gy. (ed.): Munkajog, Dialóg Campus, Budapest,

Körmendi, L. - Tóth, A. (2002): A controlling tudományos megközelítése és alkalmazása, Budapest, Perfekt,

Körmendi, L. - Tóth, A. (2006): A controlling elmélete és gyakorlata. Perfekt Kiadó Zrt. Budapest.

Kun, A. (2019): A valódi munkaidő-szuverenitás nyomában, In: Bankó, Z. et al. (ed.) Ünnepi tanulmányok Lörincz György 70. születésnapja tiszteletére, HVG-ORAC Lap- és Könyvkiadó Kft., Budapest,

Lee, S., McCann, D., Messer J. C. (2007): Working Time Around the World, London, Routledge,

Lipták, K. (2013): A globalizáció hatása a regionális munkaerőpiacokra - kiegyenlítődés vagy leszakadás? Ph.D. Dissertation, Miskolc, 201 p.

Maczó, K. (ed.) (2001): Controlling a gyakorlatban, Budapest, Verlag Dashöfer,

Máté, D. A. (2018): A munkaidő szervezése és a munkamorál összefüggései, Miskolci Jogtudó, 2018/1., pp. 1-8.

Musinszki, Z., Mélypataki, G., Lipták, K. (2019): A digitalizáció és a kontroller In: Veresné, Somosi M.; Lipták, K. (ed.) "Mérleg és Kihívások" XI. Nemzetközi Tudományos Konferencia Miskolc, Miskolci Egyetem Gazdaságtudományi Kar, pp. 429-436.

Nácsa, Cs. (2020): A kontrollerek feladatai és kompetenciái az álláshirdetések alapján. University of Miskolc, TDK Thesis,

Polonkai E., Szucsne Markovics, K. (2018): The Social Role of Intership Programmes in Reducing Migration from a County Seat; Theory Methodology Practice: Club of Economics in Miskolc (1589-3413 2415-9883): 14 (2) pp. 39-55. 


\section{International Conference on New Trends in \\ Management, Business and Economics}

25-27 June 2021 - Vienna, Austria

Sipka, P., Zaccaria, M. L. (2019): A munka és a magánélet közötti egyensúly kialakításának alapvető követelményeiről a 2019/1158 irányelvre figyelemmel, Munkajog 2020/1, pp. 24-30.

Solti, G. (2013): Mitől lesz sikeres egy controller? https://www.controllingportal.hu/mitol_lesz_sikeres_egy_controller_/[Downloaded: 2019. 07. 14]

Szucsne Markovics, K. (2015): A társadalmi vállalkozások finanszírozási lehetőségei; In: Ferencz Árpád (Ed.): II. Gazdálkodás és Menedzsment Tudományos Konferencia: "A vidék él és élni akar"; Kecskemét: Kecskeméti Főiskola Kertészeti Főiskolai Kar, pp. 676-680.

Szucsne Markovics, K. (2019): A hazai kis- és közepes vállalatok társadalmi problémák iránti érzékenysége egy kérdőíves felmérés tapasztalatai alapján; Észak-Magyarországi Stratégiai Füzetek (1786-1594 2560-2926): 16 (1), pp. 59-75.

Tóth, A., Zéman, Z. (2017): Stratégiai pénzügyi controlling és menedzsment. Akadémia Kiadó, Budapest,

Tóth, H., Prugberger, T. (2020): A munkáltatók munkavállalók irányában fennálló tájékoztatási kötelezettségének várható alakulása az átlátható és kiszámítható munkafeltételekről szóló új irányelv alapján, Magyar Jog 2020/1, pp. 30-33.

Veresné Somosi, M., Balaton, K. (2020): A társadalmi innováció fogalma. In: Smuk, P. (ed.) Társadalmi fenntarthatóság, Budapest: Ludovika Egyetemi Kiadó pp. 19-36.

Veresné Somosi, M., Varga, K. (2021): Conceptualisation as a tool in understanding social innovation - methods, case studies, practices. University of Miskolc 